Sains Malaysiana 50(1)(2021): 191-199

http://dx.doi.org/10.17576/jsm-2021-5001-19

\title{
The Impact of Diabetic Peripheral Neuropathy on Spatiotemporal Gait Parameters in Stroke Survivors: A Case-Control Study
}

(Kesan Diabetik Neuropati Periferi ke atas Parameter Berjalan dalam Aspek Masa dan Jarak dalam Kalangan Pesakit Strok: Suatu Kajian Kes Kawalan)

\author{
Amirah Mustapa, Maria Justine, Nadia Mohd Mustafah \& Haidzir ManaF*
}

\begin{abstract}
The deterioration of gait performance following stroke is related to the impairment of sensorimotor function on the paretic side. Improper gait performance in post-stroke with additional diabetic peripheral neuropathy (DPN) on paretic and non-paretic legs may create destabilizing effects, including serious injuries and falls. Therefore, this study aimed to investigate the effect of DPN on spatiotemporal gait parameters in stroke survivors and determine the correlation of movement functioning and functional balance post-stroke with gait parameters. Ten stroke survivors with DPN, 10 stroke survivors without DPN and 10 healthy controls participated in this case-control study. Movement functioning and functional balance were assessed before the actual testing. Spatiotemporal gait parameters were recorded using the Nexus Vicon motion analysis system. Kruskal-Wallis test was used to analyze the gait parameters and Spearman's rank-order correlation coefficient was used to identify the correlation between variables. Results showed that stroke survivors with DPN had longer stride time (temporal gait parameter, $p=0.001$ ), lower cadence $(p=0.001)$ and greater gait variability than those without DPN and the healthy controls. The gait parameters were significantly correlated with movement functioning and functional balance in stroke survivors with DPN ( $p<0.05)$. These findings suggested that DPN possibly affected the gait parameters in stroke survivors. DPN could also play a role in movement functioning and functional balance in stroke survivors.
\end{abstract}

Keywords: Diabetic peripheral neuropathy; gait; spatiotemporal; stroke

\section{ABSTRAK}

Kecelaruan fungsi berjalan dalam kalangan pesakit strok dilaporkan kerana masalah fungsi sensorimotor pada sisi lumpuh. Kecelaruan fungsi berjalan dalam kalangan pesakit strok dengan pertambahan gangguan sarafkaki akibat kencing manis pada sisi lumpuh dan baik boleh menimbulkan kesan buruk yang boleh mempengaruhi risiko jatuh. Oleh itu, kajian ini ingin mengkaji kesan gangguan saraf kaki akibat kencing manis terhadap parameter berjalan dalam aspek masa dan jarak dalam kalangan pesakit strok dan menentukan hubung kait antara fungsi pergerakan, keseimbangn badan dengan parameter berjalan. Sepuluh pesakit strok dengan gangguan saraf kaki akibat kencing manis, 10 pesakit strok yang tiada gangguan saraf kaki akibat kencing manis dan 10 peserta yang sihat telah menyertai kajian ini. Fungsi pergerakan dan keseimbangn badan diuji sebelum ujian yang sebenar. Parameter berjalan dalam aspek masa dan jarak dirakam menggunakan sistem analisis pergerakan Nexus Vicon. Ujian Kruskal-Wallis telah digunakan untuk menganalisis parameter berjalan dan pekali korelasi tataan peringkat Spearman telah digunakan untuk mengenali hubung kait antara pemboleh ubah. Kajian ini menunjukkan pesakit strok dengan gangguan saraf kaki akibat kencing manis mempunyai masa melangkah yang lebih panjang (parameter berjalan dalam aspek masa), jumlah langkah yang rendah dalam satu minit dan kelainan berjalan yang besar daripada pesakit strok yang tiada gangguan saraf kaki akibat kencing manis dan peserta yang sihat. Parameter berjalan mempunyai hubung kait yang signifikan dengan fungsi pergerakan dan keseimbangn badan pada pesakit strok dengan gangguan saraf kaki akibat kencing manis. Keputusan ini mencadangkan parameter berjalan pada pesakit strok terjejas kerana gangguan saraf kaki akibat kencing manis. Gangguan saraf kaki akibat kencing manis juga memainkan peranan penting dalam keterukan strok dan keseimbangn badan.

Kata kunci: Aspek masa dan jarak; berjalan; gangguan saraf kaki akibat kencing manis; strok 


\section{INTRODUCTION}

Diabetic peripheral neuropathy (DPN) is a long-term complication of diabetes mellitus. Individuals with DPN present with a symmetrical loss of sensation in the arms, hands, legs and feet and DPN eventually affect these individuals' gait performance (Dixit \& Maiya 2014; Menz et al. 2004). Previous studies have shown that individuals with DPN present with gait deviations, such as decreased gait speed (Katoulis et al. 1997; Menz et al. 2004), decreased stride length, increased stride time, increased double support time and reduced cadence (Martinelli et al. 2013; Menz et al. 2004; Najafi et al. 2013). These characteristics could be related to a safety strategy that allows the individuals more time to react with the obstacles or environmental changes (Manor et al. 2008). Neuropathic gait is also characterized by an increase in gait variability (Dingwell \& Cavanagh 2001), which is linked to increased risk of falls (Wuehr et al. 2014). While falls have been associated with neuropathy in patients with diabetes, the effect of DPN on the gait performance of stroke survivors is unclear.

Deterioration of gait performance is one of the major functional limitations in stroke survivors. Their poor gait coordination is characterized by asymmetries in propulsive forces between the paretic and non-paretic legs (Balaban \& Tok 2014; Beyaert et al. 2015). Stroke survivors have difficulty in weight shifting onto the paretic leg (Shaughnessy et al. 2005). As a result, they adopt a compensatory strategy of increased body weight bearing toward the non-paretic leg during walking (Hsu et al. 2003; Raja et al. 2012). In the present study, the gait performance of stroke survivors who have additional loss of sensation on their non-paretic leg displayed increased gait instability and high risk of falls.

To the best of the authors' knowledge, all previous studies on the deterioration of gait parameters due to DPN and stroke have been carried out separately. The present study aimed to investigate the effect of DPN on spatiotemporal gait parameters and gait variability in stroke survivors and the correlations of movement functioning and functional balance with spatiotemporal gait parameters in stroke survivors with and without DPN. The hypothesis was that spatiotemporal gait parameters and gait variability are more severely disrupted in stroke survivors with DPN than in those without DPN or in healthy controls.

\section{MATERIALS AND METHODS}

Ten stroke survivors with DPN (nine males, one female), 10 stroke survivors without DPN (seven males, three females) and 10 healthy controls (three males, seven females) participated in this case-control study. Participants who had hemorrhagic and/or ischemic stroke for the first time were recruited from a government-funded hospital through purposive sampling. Stroke survivors with DPN were included in the study if they: had stroke at least 6 months prior, had type 2 diabetes mellitus based on the medical record and tested positive for DPN based on the Semmes-Weinstein monofilament examination (SWME) and vibration test using a $128-\mathrm{Hz}$ tuning fork, were able to obey three-step commands, and were able to walk $10 \mathrm{~m}$ without aid. Stroke survivors without DPN were included if they: had stroke at least 6 months' prior, were able to obey three-step commands, and were able to walk $10 \mathrm{~m}$ without aid. Participants were excluded from the study if they had severe musculoskeletal problems, foot ulcers, botulinum toxin treatment or diseases other than diabetes mellitus that cause peripheral neuropathy (e.g. HIV and claudication). Participants were also excluded if they had any visual field defects or used orthoses. Healthy controls were recruited from the hospital staff or the caregivers of the participants. The institutional ethics committee of the Universiti Teknologi MARA approved the study (600-IRMI-5/1/6).

After the informed consent forms were signed, a preliminary investigation, including demographic measures was implemented. DPN was diagnosed based on a standardized clinical examination using SWME and 128-Hz tuning fork (Menz et al. 2004). A combination of the SWME and tuning fork test was the most sensitive (69.7-72.5\%) and accurate (79.7-81.4\%) in detecting DPN with $89.5 \%$ sensitivity and $84.9 \%$ specificity (AlGeffari 2012). SWME was conducted from medial foot sites to tibial sites to test the typical stocking pattern distribution in DPN (Tanenberg 2009). The Motricity Index and the Stroke Rehabilitation Assessment of Movement (STREAM) were used to measure muscle strength and movement functioning (Ahmed et al. 2003). The Berg Balance Scale (BBS), a proven psychometrically sound measure of functional balance deficit in stroke survivors, was also employed (Blum \& Korner-Bitensky 2008).

Gait analysis was conducted in a gait lab equipped with a Nexus Vicon 612 motion analysis system (Oxford Metrics; Oxford, UK) with eight cameras (MX-F20) recording at a sampling rate of $100 \mathrm{~Hz}$. Anthropometric measurements, including leg length, knee width and ankle width were entered into the Plug-in Gait (PiG) modeling software (Vicon, Oxford Metrics). On the basis of the PiG marker placement model, a total of 16 retroreflective spherical markers were placed bilaterally on the following anatomical landmarks: anterior superior iliac spine, posterior superior iliac spine, mid-thigh, lateral fibular head, mid-calf, lateral malleolus, base of the first metatarsal and calcaneus (Ko et al. 2011). The participants were asked to walk barefoot for $5 \mathrm{~m}$ on a platform at their habitual gait speed. Three practice trials were performed to familiarize the participants with the 
test before implementing five test trials with a 5-min rest between each. The 5-min rest was crucial for minimizing fatigue effects (Mustapa et al. 2017).

The raw marker data collected using the motion capture system were filtered at $10 \mathrm{~Hz}$ via a low-pass fourthorder Butterworth filter. Given that this study aimed to determine the effect of DPN on stroke survivor's paretic legs, the data collection was focused on comparing these paretic legs with the same legs of the healthy controls. Data from each gait cycle from the four trials were averaged to overcome the effects of stride-to-stride variability (Boudarham et al. 2013). The best three recorded trials were chosen for statistical analysis and the average spatiotemporal gait parameters were determined. The coefficient of variation $(\mathrm{CV})$ of each gait parameter was calculated using the following equation (1) (Wuehr et al. 2014):

$$
\mathrm{CV}=(\mathrm{SD} / \mathrm{mean}) \times 100
$$

Shapiro-Wilk test was used to test for normality. Nonparametric statistics were used and statistical analyses were performed on SPSS software version 20.0
(IBM, Armonk, New York). Kruskal-Wallis test was used to compare the spatiotemporal gait parameters of the three groups. Statistical significance was set at $p<0.05$. When significant changes were observed, post hoc comparisons using Mann-Whitney $\mathrm{U}$ test with Bonferroni correction were performed to compare the two clusters with the level of significance set at $\mathrm{p}<0.016$. Spearman's rankorder correlation coefficients $(r)$ were used to investigate the correlation of movement functioning and functional balance with gait parameters (gait speed, stride length, stride time, double support time, and cadence). Based on Portney and Watkins's guidelines, the $r_{s}$ of $0.00-0.25$, $0.25-0.50,0.50-0.75$ and $>0.75$ indicate no association, small association, moderate to good association and excellent association respectively (Portney \& Watkins 2014).

\section{RESULTS}

The participants' characteristics are presented in Table 1. Among the 20 participants who suffered from stroke, 10 had left hemiparesis. The participants' spatiotemporal gait parameters are presented in Table 2.

TABLE 1. Demographic information of participants

\begin{tabular}{|c|c|c|c|c|c|c|c|}
\hline \multirow{2}{*}{ Characteristics } & \multicolumn{2}{|c|}{ SDPN $(n=10)$} & \multicolumn{2}{|c|}{$\mathrm{S}(\mathrm{n}=10)$} & \multicolumn{2}{|c|}{$\mathrm{HC}(\mathrm{n}=10)$} & \multirow{2}{*}{$\begin{array}{c}P- \\
\text { value }\end{array}$} \\
\hline & Median & range & Median & range & Median & range & \\
\hline Age (years) & 58 & $50-65$ & 54.5 & $41-65$ & 50 & $41-61$ & 0.051 \\
\hline Weight (kg) & 70.5 & $0.9-103$ & 72.1 & $64.4-88.65$ & 67.35 & $50.5-82$ & 0.223 \\
\hline Height (cm) & 161.1 & $156-180$ & 162.1 & $152.8-170$ & 154.2 & $141.6-174$ & $0.033^{*}$ \\
\hline Duration of stroke (months) & 23.5 & $8-60$ & 28.5 & $8-60$ & - & - & 0.594 \\
\hline Duration of DM (years) & 19 & $10-28$ & - & - & - & - & - \\
\hline Tactile sensation (SWME) & \multicolumn{2}{|c|}{$\begin{array}{l}\text { P and NP: } \\
\text { Absence: } 1 \\
\text { Impaired: } 9\end{array}$} & \multicolumn{2}{|c|}{$\begin{array}{l}\text { P: Impaired: } 9 \\
\quad \text { Normal: } 1 \\
\text { NP: Normal: } 10\end{array}$} & & - & - \\
\hline $\begin{array}{l}\text { Muscle strength (Motricity } \\
\text { Index) (max score: 99) }\end{array}$ & $\begin{array}{l}\text { P: } 44.5 \\
\text { NP: } 63\end{array}$ & $\begin{array}{l}\text { P: } 27-75 \\
\text { NP: } 57-99\end{array}$ & $\begin{array}{l}\text { P: } 57 \\
\text { NP: } 75\end{array}$ & $\begin{array}{l}\text { P: } 47-75 \\
\text { NP: } 75-99\end{array}$ & 99 & $75-99$ & $\begin{array}{l}0.00^{*} \\
0.00^{*}\end{array}$ \\
\hline $\begin{array}{l}\text { Stroke severity (STREAM) } \\
\text { (max score: } 70)\end{array}$ & 57.21 & $42.2-69$ & 66.79 & $52.5-69$ & - & - & $0.00^{*}$ \\
\hline $\begin{array}{l}\text { Functional Balance (BBS) } \\
\text { (max score: } 56)\end{array}$ & 35.5 & $23-53$ & 48 & $43-55$ & 55 & $51-56$ & $0.00 *$ \\
\hline
\end{tabular}

$* p<.05$; Kruskal-Wallis test, $* * p<.016$; Mann- Whitney U test

HC: healthy controls; P: Paretic; NP: Non-paretic; S: stroke survivors without DPN; SDPN: stroke survivors with DPN. 
TABLE 2. Correlation between stroke severity (STREAM) and functional balance (BBS) with spatiotemporal gait parameters in stroke survivors with and without DPN

\begin{tabular}{|c|c|c|c|c|}
\hline \multirow[b]{2}{*}{$\begin{array}{c}\text { Spatiotemporal gait } \\
\text { parameters }\end{array}$} & \multicolumn{2}{|c|}{$\operatorname{SDPN}(n=10)$} & \multicolumn{2}{|c|}{$S(n=10)$} \\
\hline & $\begin{array}{l}\text { Stroke severity } \\
\text { (STREAM) }\end{array}$ & $\begin{array}{l}\text { Functional balance } \\
\text { (BBS) }\end{array}$ & $\begin{array}{l}\text { Stroke severity } \\
\text { (STREAM) }\end{array}$ & $\begin{array}{c}\text { Functional balance } \\
\text { (BBS) }\end{array}$ \\
\hline Gait speed paretic side & $\begin{array}{c}\mathrm{r}_{\mathrm{s}}=0.72 \\
p=0.020^{*}\end{array}$ & $\begin{array}{c}\mathrm{r}_{\mathrm{s}}=0.73 \\
p=0.019^{*}\end{array}$ & $\begin{array}{l}r_{s}=-0.23 \\
p=0.519\end{array}$ & $\begin{array}{l}r_{s}=0.23 \\
p=0.527\end{array}$ \\
\hline Stride length paretic side & $\begin{array}{c}\mathrm{r}_{\mathrm{s}}=0.91 \\
p<0.001 *\end{array}$ & $\begin{array}{c}\mathrm{r}_{\mathrm{s}}=0.83 \\
p=0.003 *\end{array}$ & $\begin{array}{l}\mathrm{r}_{\mathrm{s}}=-0.31 \\
p=0.392\end{array}$ & $\begin{array}{l}r_{s}=-0.10 \\
p=0.800\end{array}$ \\
\hline Stride time paretic side & $\begin{array}{l}r_{s}=-0.60 \\
p=0.069\end{array}$ & $\begin{array}{l}\mathrm{r}_{\mathrm{s}}=-0.76 \\
p=0.011 *\end{array}$ & $\begin{array}{l}r_{s}=-0.44 \\
p=0.199\end{array}$ & $\begin{array}{c}\mathrm{r}_{\mathrm{s}}=-0.74 \\
p=0.015^{*}\end{array}$ \\
\hline $\begin{array}{c}\text { Double support time } \\
\text { paretic side }\end{array}$ & $\begin{array}{c}r_{s}=-0.76 \\
p=0.012 *\end{array}$ & $\begin{array}{l}r_{s}=-0.60 \\
p=0.067\end{array}$ & $\begin{array}{c}r_{s}=0.11 \\
p=0.762\end{array}$ & $\begin{array}{l}r_{s}=-0.139 \\
p=0.702\end{array}$ \\
\hline Cadence paretic side & $\begin{array}{l}\mathrm{r}_{\mathrm{s}}=0.60 \\
p=0.069\end{array}$ & $\begin{array}{c}\mathrm{r}_{\mathrm{s}}=0.76 \\
p=0.011 *\end{array}$ & $\begin{array}{c}\mathrm{r}_{\mathrm{s}}=0.40 \\
p=0.257\end{array}$ & $\begin{array}{c}\mathrm{r}_{\mathrm{s}} 0.72 \\
p=0.019^{*}\end{array}$ \\
\hline
\end{tabular}

$* p<.05$; Spearman's rank-order correlation coefficients

S: stroke survivors without DPN; SDPN: stroke survivors with DPN

\section{GAIT SPEED}

Stroke survivors with DPN had a significantly slower gait speed than stroke survivors without DPN and healthy controls $(p=0.001)$. However, post hoc comparisons showed no significant difference between stroke survivors with and without DPN $(\mathrm{p}=0.035)$. Both had slower gait speed than the healthy controls $(p=0.001)$. Figure 1 compares the gait speed of the three groups.
Gait speed variability differed significantly among the three groups $(\mathrm{p}=0.008)$. Post hoc comparisons showed that gait speed variability was significantly greater in stroke survivors with DPN than in those without DPN $(p=0.009)$ and in the healthy controls $(p=0.011)$. No significant difference was observed in the gait speed variability between the stroke survivors without DPN and the healthy controls $(\mathrm{p}=0.165)$.

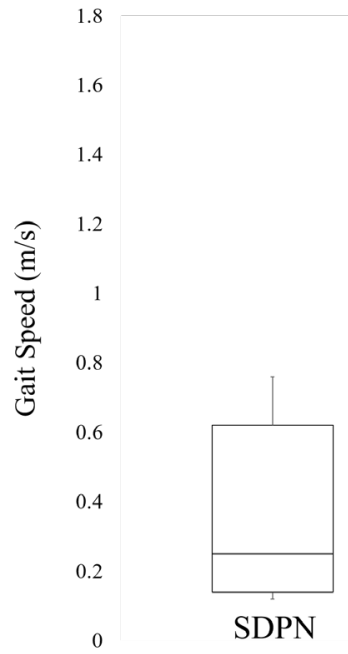

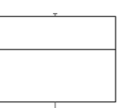

S

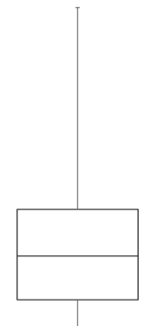

SDPN: stroke survivors with DPN S: stroke survivors without DPN $\mathrm{HC}$ : healthy controls

FIGURE 1. Gait speed during walking in the three groups 


\section{STRIDE LENGTH}

The stroke survivors with DPN had a significantly shorter stride length than those without DPN and the healthy controls $(p=0.007)$. However, post hoc comparisons did not show any significant difference between stroke survivors with and without DPN $(\mathrm{p}=0.063)$. Overall, stroke survivors had shorter stride length than the healthy controls.

Stride length variability differed significantly among the three groups $(p=0.021)$. Post hoc comparisons showed that step length variability was significantly greater in stroke survivors with DPN than in those without DPN ( $p=0.015)$. However, no significant difference was found between the stroke survivors with DPN and the healthy controls $(p=0.029)$ and between those without DPN and the healthy controls $(\mathrm{p}=0.353)$.

\section{STRIDE TIME}

Figure 2 compares the stride time of the three groups. The stroke survivors with DPN had a significantly longer stride time than those without DPN and the healthy controls $(p=0.001)$. Post hoc comparisons showed significant differences in stride time between the stroke survivors with and without DPN $(\mathrm{p}=0.002)$, between those with DPN and the healthy controls $(\mathrm{p}=0.001)$ and between those without DPN and the healthy controls $(\mathrm{p}=0.007)$. However, no significant difference was observed in the stride time variability among the three groups $(\mathrm{p}=0.187)$.

\section{DOUBLE SUPPORT TIME}

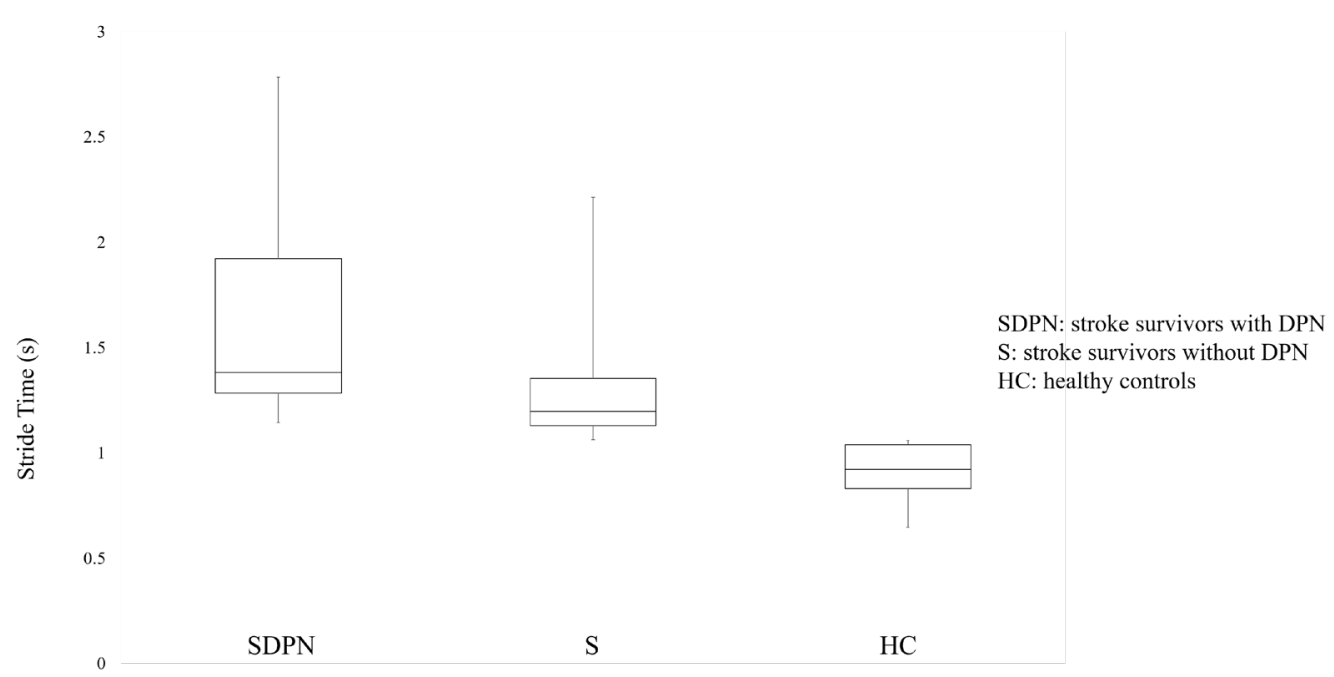

FIGURE 2. Stride time during walking in the three groups

In contrast to the stride time, no significant difference was found in double support time among the three groups ( $p$ $=0.128$ ). However, a significant difference was observed in double support time variability among the three groups $(p=0.003)$. Post hoc comparisons showed significant differences in double support time variability between the stroke survivors with and without DPN $(p=0.005)$ and between those with DPN and the healthy controls ( $\mathrm{p}$ $=0.005)$.

\section{CADENCE}

Figure 3 compares the cadence of the three groups. The stroke survivors with DPN had a significantly lower cadence than those without DPN and the healthy controls $(p=0.001)$. Post hoc comparisons showed significant differences between the stroke survivors with and without DPN ( $p=0.003)$, between those with DPN and the healthy controls $(p=0.001)$ and between those without DPN and the healthy controls $(\mathrm{p}=0.009)$. Cadence variability differed significantly among the three groups $(p=0.007)$. Post hoc comparisons showed a significant difference between the stroke survivors without DPN and the healthy controls $(p=0.002)$. However, no significant difference was observed in the cadence variability between the stroke survivors with and without DPN ( $\mathrm{p}=$ 0.019 ) and between those without DPN and the healthy controls $(\mathrm{p}=0.97)$.

Table 2 shows the correlation of STREAM and 


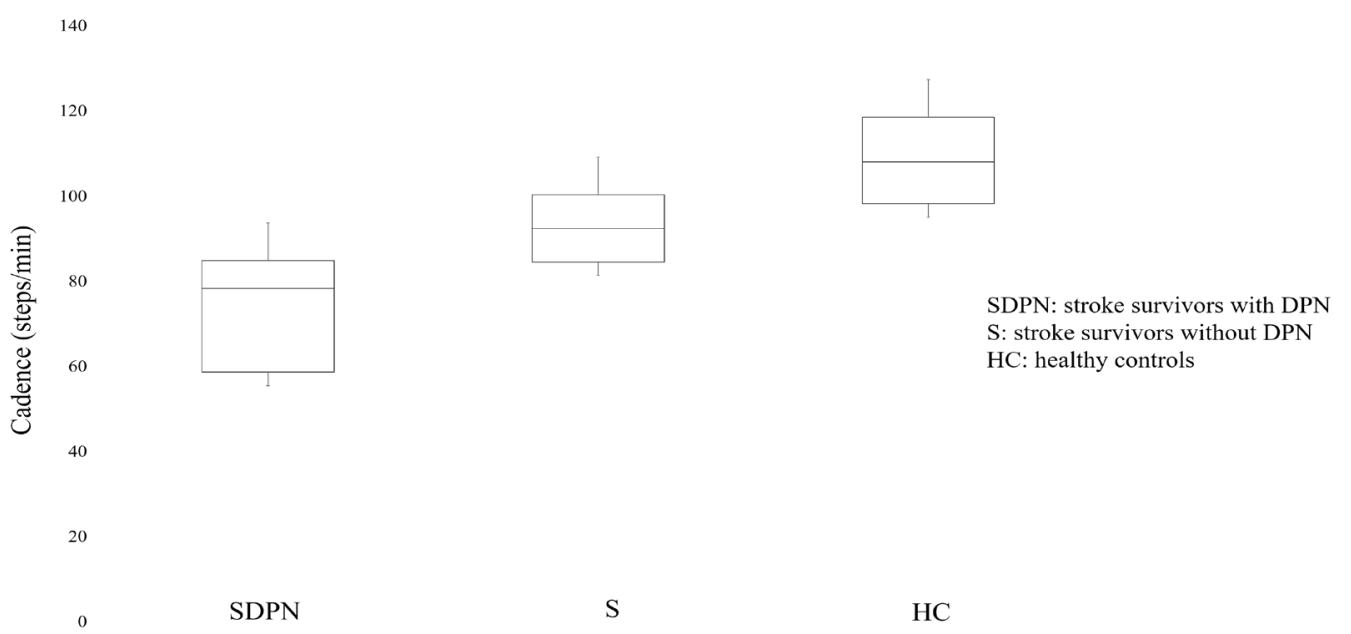

FIGURE 3. Cadence during walking in the three groups

BBS with the spatiotemporal gait parameters in stroke survivors with and without DPN. A moderate to excellent positive rank order correlation was found between STREAM and gait speed $\left(r_{s}=0.72, \mathrm{p}=0.02\right)$ and stride length $\left(r_{s}=0.91, \mathrm{p}=0.001\right)$ in stroke survivors with DPN. Furthermore, an excellent negative rank order correlation was observed between STREAM and double support time $\left(r_{s}=-0.76, \mathrm{p}=0.012\right)$ in stroke survivors with DPN.

A moderate to excellent positive rank order correlation was also found between BBS and gait speed $\left(r_{s}=0.73, \mathrm{p}=0.019\right)$, stride length $\left(r_{s}=0.83, \mathrm{p}=0.003\right)$ and cadence $\left(r_{s}=0.76, \mathrm{p}=0.011\right)$ in stroke survivors with DPN. The results also demonstrated an excellent negative rank order correlation between BBS and stride time $\left(r_{s}\right.$ $=-0.76, \mathrm{p}=0.011)$ in stroke survivors with DPN and a moderate negative rank order correlation between BBS and stride time on the paretic side $\left(r_{s}=-0.74, \mathrm{p}=0.015\right)$ in stroke survivors without DPN. In addition, a moderate positive rank order correlation was found between BBS and cadence on the paretic side $\left(r_{s}=0.72, \mathrm{p}=0.019\right)$ in stroke survivors without DPN.

\section{DISCUSSION}

To the best of the authors' knowledge, this study was the first to investigate the effect of DPN on spatiotemporal gait parameters in stroke survivors. The results showed that the stroke survivors with DPN had longer stride time (1.53 s, temporal gait parameter) instead of shorter stride length (spatial gait parameter) than those without DPN $(1.27 \mathrm{~s})$ and the healthy controls. Previous studies found that the average range of stride time in patients with DPN and stroke survivors is 1.20-1.35 s (Boudarham et al. 2013; Najafi et al. 2013). In the present study, the stroke survivors with DPN also had lower cadence (79.7 steps $\mathrm{min}^{-1}$ ) than those without DPN (95 steps $\min ^{-1}$ ) and the healthy controls (108.6 steps $\left.\mathrm{min}^{-1}\right)$. Earlier studies showed that the cadence of patients with DPN ranges between 100.6 and 102.5 steps min $^{-1}$ (Courtemanche et al. 1996; Paul et al. 2009). Other studies demonstrated that stroke survivors have a cadence ranging from 69.06 steps $\mathrm{min}^{-1}$ to 91.49 steps/min (Boudarham et al. 2013; Von Schroeder et al. 1995).

The results of the present study indicated that the longer stride time and lower cadence in stroke survivors with DPN were possibly due to the sensorimotor deficits on the paretic side, muscle weakness of the lower limbs and spasticity of the gastrocnemius and soleus muscles (Toosizadeh et al. 2015). DPN-related changes in the non-paretic side of stroke survivors may reduce sensory feedback and lead to gait performance variations, such as inhibition of compensation and adaptation to slower gait on the non-paretic side (Menz et al. 2004). However, the implications of DPN on stride time and cadence in stroke survivors are unclear due to comparable muscle strength, movement functioning and functional balance in between stroke survivors with and without DPN. This circumstance may contribute to the variability of the findings of this study, thereby indicating its limitation.

Another possible explanation for this finding may be related to the strategy chosen by the participants. The stroke survivors with DPN were hypothesized to have decreased gait speed and stride length, which lead to increased stride time, increased double support time and decreased cadence. The findings corroborated the idea 
that slow gait speed and low cadence may improve the probability of successful balance recovery by reducing the forward momentum of the body (Courtemanche et al. 1996; Espy et al. 2010). This finding further supported the idea that individuals with DPN who lost their sensory feedback could improve their gait stability by lowering their gait speed (Dingwell \& Cavanagh 2001). In patients with DPN, sensory systems are utilized to clear unintended irregularities during unperturbed locomotion and for balance maintenance during walking (Wuehr et al. 2004). Therefore, decreased gait speed may also be a strategy for stroke survivors with DPN to improve or maintain gait stability to avoid falls.

By contrast, the spatiotemporal gait parameters in the healthy subjects were better than those in stroke survivors. Several hypotheses could be determined from this finding. First, the gait testing procedure could cause stroke survivors to create adaptations to walking because the test was conducted in the gait lab with participants barefoot and with markers taped onto their lower limbs. Second, the involvement of psychological factors, such as fear of falling or anxiety, may deteriorate the gait performance of stroke survivors (Rosen et al. 2005). Third, the presence of spasticity and muscle weakness may also impair their gait performance. Previous studies showed that the strength of hip flexors and knee extensors is the most important element in determining gait speed during regular walking (Hsu et al. 2003).

Another interesting observation from the present study was the significantly increased gait variability in stroke survivors with DPN. This result was consistent with that of previous studies where gait variability is increased in individuals with DPN (Dingwell \& Cavanagh 2001; Wuehr et al. 2014). The increase in gait variability is speculated to result from disturbances in the rhythmic stepping mechanism which depends on the central nervous system to produce an efficient gait pattern (Bauchet et al. 2009). Thus, stroke survivors with sensorimotor function impairments on hemiparetic and sound sides may compensate the deterioration in gait performance by reducing their self-selected walking speed, thereby contributing to increased step variability (Ricci et al. 2015).

Moderate to excellent correlations were found between movement functioning and gait speed, double support time, and stride length. This finding corroborated the result of a study by Bowden et al. (2010), who found that movement functioning (using the FuglMeyer Assessment) is significantly correlated with gait speed. The severity of post-stroke symptoms, such as paralysis (Jongbloed 1986), spasticity (Ward 2012) and muscle weakness (Beyaert et al. 2015), explains the correlation between movement functioning and gait parameters. In stroke survivors without DPN, no significant correlation was found between movement functioning and spatiotemporal gait parameters, likely because the movement functioning of stroke survivors without DPN was lower and did not impair their gait performance compared with those with DPN.

Improving functional balance during various activities is needed to regain optimal functional independence post-stroke. In stroke survivors with DPN, significant correlations were observed between functional balance and gait speed, stride length, stride time, and cadence. These findings were consistent with those of the study by Kluding and Gajewski (2009), who demonstrated a significant relationship between functional balance and gait speed in patients who suffered from stroke. In individuals with DPN, inaccurate proprioceptive feedback and progressive impairment to the somatosensory, visual, and vestibular systems cause balancing difficulties during walking (Fahmy et al. 2013; Fortaleza et al. 2012). In patients who suffered from stroke, somatosensory (Kluding \& Gajewski 2009), visual (Ng \& Fong 2014) and vestibular impairments (Haral et al. 2014; Tyson et al. 2006) cause balance disturbances in gait performance (Garland et al. 2009). Thus, sufficient range of motion, muscular strength and proprioceptive feedback from the lower limb joints are required to maintain gait stability. However, these functions are compromised in stroke survivors (Kluding \& Gajewski 2009).

In stroke survivors without DPN, excellent negative and positive rank correlations were found between functional balance and stride time and cadence, possibly due to the balance strategy of changing the temporal gait pattern, that is, longer time spent in the stance phase on the non-paretic side while prolonging the swing phase on the paretic side (Wolley 2001).

This study had several limitations. First, the results were obtained from a relatively small sample size and may not be generalized to other individuals who had a stroke. Second, this study relied solely on the combination of clinical measures (SWME and use of turning fork) and the medical records to identify and categorize stroke survivors with DPN. Using a vibration perception threshold of less than 25 is recommended to identify patients with DPN in future studies (de Mettelinge et al. 2013). Third, the stroke survivors with and without DPN had comparable muscle strength, movement functioning, and functional balance. This circumstance may contribute to the variability of the implication of DPN on the gait parameters in stroke survivors. Finally, the data analysis was limited to a bivariate analysis of the spatiotemporal gait parameters that violated the assumptions of a multivariate analysis. Therefore, whether DPN is the main reason behind the impaired gait performance of stroke survivors with DPN remains questionable. 
In summary, DPN possibly affected the gait parameters in stroke survivors with DPN in the aspect of increased stride time (temporal gait parameter), decreased cadence and greater gait variability compared with those in stroke survivors without DPN and healthy controls. In addition, the correlation of movement functioning and functional balance with spatiotemporal gait parameters was greater in stroke survivors with DPN that in those without DPN. These findings were consistent with the hypotheses of this study. However, further investigations with non-comparable functional status at baseline in stroke survivors with and without DPN are warranted to gain enhanced insights into the relationship between DPN and gait in stroke survivors.

\section{ACKNOWLEDGEMENTS}

The authors thank the Ministry of Education, Malaysia for funding this research through the FRGS grant (600RMI/FRGS 5/3 54/2015). The authors declare that there is no conflict of interests regarding the publication of this paper.

\section{REFERENCES}

Ahmed, S., Mayo, N.E., Higgins, J., Salbach, N.M., Finch, L. \& Wood-Dauphinée, S.L. 2003. The stroke rehabilitation assessment of movement (STREAM): A comparison with other measures used to evaluate effects of stroke and rehabilitation. Physical Therapy 83(7): 617-630.

Al-Geffari, M. 2012. Comparison of different screening tests for diagnosis of diabetic peripheral neuropathy in primary health care setting. International Journal of Health Sciences 6(2): 127-134

Balaban, B. \& Tok, F. 2014. Gait disturbances in stroke patients. The Journal of Injury, Function and Rehabilitation 6(7): 635-642.

Beauchet, O., Annweiler, C., Lecordroch, Y., Allali, G., Dubost, V., Herrmann, F.R. \& Kressig, R.W. 2009. Walking speed-related changes in stride time variability: Effects of decreased speed. Journal of Neuroengineering and Rehabilitation 6(1): 22-29.

Beyaert, C., Vasa, R. \& Frykberg, G.E. 2015. Gait poststroke: Pathophysiology and rehabilitation strategies. Neurophysiologie Clinique/Clinical Neurophysiology 45(45): 335-355.

Blum, L. \& Korner-Bitensky, N. 2008. Usefulness of the Berg Balance Scale in stroke rehabilitation: A systematic review. Physical Therapy 88(5): 559-566.

Boudarham, J., Roche, N., Pradon, D., Bonnyaud, C., Bensmail, D. \& Zory, R. 2013. Variations in kinematics during clinical gait analysis in stroke patients. PloS ONE 8(6): e66421.

Bowden, M.G., Clark, D.J. \& Kautz, S.A. 2010. Evaluation of abnormal synergy patterns poststroke: Relationship of the Fugl-Meyer assessment to hemiparetic locomotion. Neurorehabilitation and Neural Repair 24(4): 328-337.

Courtemanche, R., Teasdale, N., Boucher, P., Fleury, M., Lajoie, Y. \& Bard, C. 1996. Gait problems in diabetic neuropathic patients. Archives of Physical Medicine and Rehabilitation 77(9): 849-855.

de Mettelinge, T.R., Delbaere, K., Calders, P., Gysel, T., Van Den Noortgate, N. \& Cambier, D. 2013. The impact of peripheral neuropathy and cognitive decrements on gait in older adults with type 2 diabetes mellitus. Archives of Physical Medicine and Rehabilitation 94(6): 1074-1079.

Dingwell, J.B. \& Cavanagh, P.R. 2001. Increased variability of continuous overground walking in neuropathic patients is only indirectly related to sensory loss. Gait \& Posture 14(1): $1-10$

Dixit, S. \& Maiya, A. 2014. Diabetic peripheral neuropathy and its evaluation in a clinical scenario: A review. Journal of Postgraduate Medicine 60(1): 33-35.

Espy, D.D., Yang, F., Bhatt, T. \& Pai, Y.C. 2010. Independent influence of gait speed and step length on stability and fall risk. Gait \& Posture 32(3): 378-382.

Fahmy, I.M., Ramzy, G.M., Salem, N.A., Ahmed, G.M. \& Mohammed, A.A. 2014. Balance disturbance in patients with diabetic sensory polyneuropathy. Egyptian Journal of Neurology, Psychiatry and Neurosurgery 51(1): 21-29.

Fortaleza, A.C.D.S., Chagas, E.F., Ferreira, D.M.A., Mantovani, A.M., Barela, J.A., Chagas, E.F.B. \& Fregonesi, C.E.P.T. 2013. Postural control and functional balance in individuals with diabetic peripheral neuropathy. Revista Brasileira de Cineantropometria \& Desempenho Humano 15(3): 305314.

Garland, S.J., Gray, V.L. \& Knorr, S. 2009. Muscle activation patterns and postural control following stroke. Motor Control 13(4): 387-411.

Haral, P.P., Yardi, S. \& Karajgi, A. 2014. Effect of sensorimotor integration on balance and gait in chronic stroke patients. Indian Journal of Physiotherapy and Occupational Therapy 8(1): 64-70.

Hsu, A.L., Tang, P.F. \& Jan, M.H. 2003. Analysis of impairments influencing gait velocity and asymmetry of hemiplegic patients after mild to moderate stroke. Archives of Physical Medicine and Rehabilitation 84(8): 1185-1193.

Jongbloed, L. 1986. Prediction of function after stroke: A critical review. Stroke 17(4): 765-776.

Katoulis, E.C., Ebdon-Parry, M., Lanshammar, H., Vileikyte, L., Kulkarni, J. \& Boulton, A.J. 1997. Gait abnormalities in diabetic neuropathy. Diabetes Care 20(12): 1904-1907.

Kluding, P. \& Gajewski, B. 2009. Lower-extremity strength differences predict activity limitations in people with chronic stroke. Physical Therapy 89(1): 73-81.

Ko, S.U., Stenholm, S., Chia, C.W., Simonsick, E.M. \& Ferrucci, L. 2011. Gait pattern alterations in older adults associated with type 2 diabetes in the absence of peripheral neuropathyresults from the baltimore longitudinal study of aging. Gait \& Posture 34(4): 548-552.

Manor, B., Wolenski, P. \& Li, L. 2008. Faster walking speeds increase local instability among people with peripheral neuropathy. Journal of Biomechanics 41(13): 2787-2792.

Martinelli, A.R., Mantovani, A.M., Nozabieli, A.J.L., Ferreira, D.M.A., Barela, J.A., de Camargo, M.R. \& Fregonesi, C.E.P.T. 2013. Muscle strength and ankle mobility for the gait parameters in diabetic neuropathies. The Foot 23(1): 17-21. 
Menz, H.B., Lord, S.R., St George, R. \& Fitzpatrick, R.C. 2004. Walking stability and sensorimotor function in older people with diabetic peripheral neuropathy. Archives of Physical Medicine and Rehabilitation 85(2): 245-252.

Mustapa, A., Justine, M., Mustafah, N.M. \& Manaf, H. 2017. The effect of diabetic peripheral neuropathy on ground reaction forces during straight walking in stroke survivors. Rehabilitation Research and Practice 2017: 1-9.

Najafi, B., Khan, T., Fleischer, A. \& Wrobel, J. 2013. The impact of footwear and walking distance on gait stability in diabetic patients with peripheral neuropathy. Journal of the American Podiatric Medical Association 103(3): 165-173.

Ng, S.S. \& Fong, S.S. 2014. Visual perception correlates with balance and motor performance in patients with stroke. Indian Journal of Physiotherapy \& Occupational Therapy 8(1): 54-59.

Paul, L., Ellis, B.M., Leese, G.P., McFadyen, A.K. \& McMurray, B. 2009. The effect of a cognitive or motor task on gait parameters of diabetic patients, with and without neuropathy. Diabetic Medicine 26(3): 234-239.

Portney, L.G. \& Watkins, P.M. 2014. Foundations of Clinical Research: Applications to Practice. 3rd ed. Upper Saddle River: Pearson Education Limited. pp. 569-584.

Raja, B., Neptune, R.R. \& Kautz, S.A. 2012. Coordination of the non-paretic leg during hemiparetic gait: Expected and novel compensatory patterns. Clinical Biomechanics 27(10): 1023-1030.

Ricci, N.A., Ferrarias, G.P., Molina, K.I., Dib, P.M. \& Alouche, S.R. 2015. Gait speed and falls self-efficacy in individuals with hemiparesis after stroke. Fisioter. Pesqui. 22(2): 191196.

Rosén, E., Sunnerhagen, K.S. \& Kreuter, M. 2005. Fear of falling, balance and gait velocity in patients with stroke. Physiotherapy Theory and Practice 21(2): 113-120.

Shaughnessy, M., Michael, K.M., Sorkin, J.D. \& Macko, R.F. 2005. Steps after stroke: Capturing ambulatory recovery. Stroke 36(6): 1305-1307.

Tanenberg, R.J. 2009. Diabetic peripheral neuropathy: Painful or painless. Hospital Physician 45(7): 1-8.

Toosizadeh, N., Mohler, J., Armstrong, D.G., Talal, T.K. \& Najafi, B. 2015. The influence of diabetic peripheral neuropathy on local postural muscle and central sensory feedback balance control. PloS ONE 10(8): e0135255.

Tyson, S.F., Hanley, M., Chillala, J., Selley, A. \& Tallis, R.C. 2006. Balance disability after stroke. Physical Therapy 86(1): 30-38.

Von Schroeder, H.P., Coutts, R.D., Lyden, P.D., Billings, E. \& Nickel, V.L. 1995. Gait parameters following stroke: A practical assessment. Journal of Rehabilitation Research and Development 32(1): 25-31.

Ward, A.B. 2012. A literature review of the pathophysiology and onset of post-stroke spasticity. European Journal of Neurology 19(1): 21-27.

Woolley, S.M. 2001. Characteristics of gait in hemiplegia. Topics in Stroke Rehabilitation 7(4): 1-18.

Wuehr, M., Schniepp, R., Schlick, C., Huth, S., Pradhan, C., Dieterich, M., Brandt, T. \& Jahn, K. 2014. Sensory loss and walking speed related factors for gait alterations in patients with peripheral neuropathy. Gait \& Posture 39(3): 852-858.

Amirah Mustapa

Department of Physical Rehabilitation Sciences

Kulliyyah of Allied Health Sciences

International Islamic University Malaysia

25200 Kuantan, Pahang Darul Makmur

Malaysia

Maria Justine \& Haidzir Manaf*

Centre of Physiotherapy, Faculty of Health Sciences

Universiti Teknologi MARA, Puncak Alam Campus

42300 Puncak Alam, Selangor Darul Ehsan

Malaysia

Haidzir Manaf*

Clinical and Rehabilitation Research Group

Faculty of Health Sciences

Universiti Teknologi MARA, Puncak Alam Campus

42300 Puncak Alam, Selangor Darul Ehsan

Malaysia

Nadia Mohd Mustafah

Department of Rehabilitation Medicine

Faculty of Medicine

Universiti Teknologi MARA, Sungai Buloh Campus

47000 Sungai Buloh, Selangor Darul Ehsan

Malaysia

*Corresponding author; email: haidzir5894@uitm.edu.my

Received: 1 February 2019

Accepted: 17 June 2020 